4 Gabriella Cobellis ${ }^{\mathrm{a}, \mathrm{b}, *}$, Massimo Trabalza-Marinucci ${ }^{\mathrm{a}}$, Maria Carla Marcotullio ${ }^{\mathrm{c}}$,

6

7

\section{Evaluation of different essential oils in modulating methane and ammonia production, rumen fermentation, and rumen bacteria in vitro.}

(1)

\author{
5 Zhongtang $\mathbf{Y} \mathbf{u}^{\mathbf{b}}$
}

(1)

a Dipartimento di Medicina Veterinaria, Università degli Studi di Perugia, 06126 Perugia, Italy

${ }^{\mathrm{b}}$ Department of Animal Sciences, The Ohio State University, Columbus, OH 43210, USA

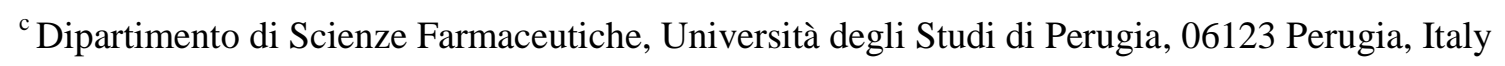

${ }^{*}$ Corresponding author at: Dipartimento di Medicina Veterinaria, Università degli Studi di Perugia, via San Costanzo 4, 06126 Perugia, Italy. Tel.: +39 0755857691; fax: +39 0755857764. E-mail address: cobellis.gabriella@gmail.com (G. Cobellis).

\section{Abbreviations:}

A/P, acetate/propionate; CCB, Ceylon cinnamon bark; CIB, cinnamon bark; CIL, cinnamon leaves; CTR, control; DGGE, Denaturing gradient gel electrophoresis; DIL, dill seeds; DM, dry matter; DMD, dry matter degradability; EO, essential oils; GHG, greenhouse gas; EUC, eucalyptus leaves; FID, flame ionization detector; GC, gas chromatography; GC-MC, gas chromatography-mass spectroscopy; NDF, neutral detergent fiber; NDFD, neutral detergent fiber degradability; ORE, oregano leaves; PCA, principal component analysis; RI, linear retention indices; ROS, rosemary leaves; SEM, standard error means; VFA, volatile fatty acids. 
Abstract

Various essential oils (EO) have been individually evaluated to mitigate methane and ammonia production by rumen microbiota. Interactions between EO can affect their potency but such interactions largely remain unexplored. In the present study, EO from oregano, rosemary, Ceylon cinnamon, cinnamon leaves, cinnamon bark, dill seeds, and eucalyptus were chemically characterized and then evaluated in vitro, both individually (at $1.125 \mathrm{ml} / \mathrm{L}$ culture) and in three-way EO combinations (at total EO $0.8 \mathrm{ml} / \mathrm{L}$, equal ratio), for their effects on fermentation, methanogenesis, ammoniagenesis, and bacteria and archaea. All the EO and their combinations decreased production of total gas $(\mathrm{P}<0.001)$, methane $(\mathrm{P}<0.001)$, and ammonia (except eucalyptus EO; $\mathrm{P}<0.001$ ), but they (except the Ceylon cinnamon-dill seeds-eucalyptus EO combination) also decreased dry matter digestibility $(\mathrm{P}<0.001)$. The EO individually decreased the abundances of Prevotella spp. $(\mathrm{P}<0.001)$ but only oregano EO reduced the abundance of archaea $(\mathrm{P}<0.001)$. The EO combinations significantly decreased the abundances of archaea $(\mathrm{P}<0.001)$, protozoa $(\mathrm{P}<0.001)$, and select groups or species of different rumen bacteria to different extents. Changes in bacterial and archaeal communities in response to several EO combinations were also shown by DGGE analyses. Combination of EO from Ceylon cinnamon, dill seeds, eucalyptus, and probably others, at low concentrations may be a practical approach to mitigate methane emission and nitrogen excretion from ruminant without adverse effect on feed digestion or fermentation.

Key words: Archaea; Essential oil; Methane; Rumen bacteria; Rumen fermentation. 


\section{Introduction}

Ruminant livestock production contributes significantly to worldwide greenhouse gas (GHG) emissions. About $71 \%$ of the GHG emissions comes as methane produced from enteric fermentation (especially rumen fermentation), followed by nitrous oxide (25\%) and methane (4\%) from manure (FAO, 2013). In the coming years, the rapid growth of world population will increase the demand for milk and meat by $22 \%$ and $14 \%$, respectively (FAO, 2013). This will inevitably increase GHG emissions from livestock production.

Numerous nutritional strategies have been evaluated in recent years to mitigate methane emission and nitrogen excretion from cattle by modulating the ruminal microbial fermentation processes. Some promising results have been obtained from natural feed additives (Hristov et al., 2013; Knapp et al., 2014). Among these natural rumen modifiers, plant secondary metabolites, such as saponins, tannins, and essential oils (EO), are of potential application.

Essential oils are synthetized by many plants as protectants against insect predation and microbial infection, and they are generally considered as safe. The major compounds identified in EO include monoterpene hydrocarbons (e.g. $\alpha$-pinene, $\alpha$-phellandrene, $p$ cymene, $m$-cymene, $\gamma$-terpinene, and limonene) and phenolic compounds (e.g. carvacrol, thymol, and eugenol). Owing to the phenolic ring and hydroxyl group, phenolic compounds have stronger antimicrobial activities than monoterpene hydrocarbons (Benchaar and Greathead, 2011; Cobellis et al., 2016). Generally, Gram-positive bacteria are more sensitive to EO than Gram-negative bacteria, but small EO compounds, such as carvacrol, are able to interact with cell membrane of Gram-negative bacteria, leading to loss of cell content and cell lysis (Benchaar and Greathead, 2011; Cobellis et al., 2016). Eugenol, a phenolic compound of cinnamon EO, can inactivate some microbial enzymes (Burt, 2004; Benchaar and Greathead, 2011). The strong antimicrobial activity of cinnamaldehyde, similar to that of 
carvacrol, has been attributed to the presence of a carbonyl group, which was thought to be able to disrupt microbial cell membrane and inactivate microbial enzymes (Benchaar and Greathead, 2011; Cobellis et al., 2016). However, unlike the antimicrobial activity exhibited by their individual compounds, the antimicrobial potency of EO varies considerably depending on chemical composition (both components present and their proportions), chemical configurations of components, and interactions among EO components (Burt, 2004). For example, cinnamon EO is more anti-methanogenic than its individual compounds, which suggests a synergic activity among its components (Macheboeuf et al., 2008). Combinations of different EO could also bring about a greater antimicrobial efficiency due to additive and/or synergistic effects that can occur between components of different EO (Benchaar and Greathead, 2011).

Recently, many EO have been shown to positively affect starch and protein degradation, production of ammonia, volatile fatty acids (VFA), and methane due to their antimicrobial activities against some ruminal microorganisms, such as methanogenic archaea and hyperammonia producing bacteria (Patra, 2011). However, these positive effects are often accompanied with negative effects on fiber degradation (Patra and $\mathrm{Yu}, 2012$ ). In fact, due to both the complexity of the rumen microbial ecosystem and EO composition, the effects of EO on different ruminal microbial populations and on their interactions with feed fermentation seem to be difficult to predict. Mixed responses of rumen microbiome to EO were also reported in different studies with respect to methane production, fermentation characteristics, and microbial populations. The chemical composition of EO, which affects their antimicrobial activities, is highly variable depending on many factors (e.g. plant species, stage of growth, parts of plant, extraction method). To date, only a few studies evaluated EO with a known chemical composition in modulating rumen microbiome and function. 
In the present study, we determined the chemical composition of seven EO and comparatively evaluated their effects on methane and ammonia production, feed degradability, VFA production, rumen bacterial and archaeal communities, and abundance of common rumen microbial groups in vitro. This study showed that combinations of certain EO could potentially decrease methane emissions from cattle with little or no detrimental effect on feed digestion or fermentation.

\section{Methods}

\subsection{Essential oils and experimental design}

Essential oil from oregano leaves (ORE; Thymus capitatus L.), rosemary leaves (ROS; Rosmarinus officinalis L.), Ceylon cinnamon bark (CCB; Cinnamomum zeylanicum), cinnamon leaves (CIL; Cinnamomum zeylanicum Blume), cinnamon bark (CIB; Cinnamomum zeylanicum Blume), dill seeds (DIL; Anethum graveolens L.), and eucalyptus leaves (EUC; Eucalyptus globulus Labill.) were purchased from Essential Srl (Montopoli Val d'Arno, Italy). The composition of the EO was determined by gas chromatography (GC) and by gas chromatography-mass spectrometry (GC-MC) that were controlled by the HP ChemStation Software. The GC instrument (HP 6890) was equipped with a MS 5973 mass selective detector (Hewlett Packard, Palo Alto, CA), a fused silica capillary column (HP5MS; $30 \mathrm{~m} \times 0.25 \mathrm{~mm}$ i.d., $0.25 \mu \mathrm{m}$ film thickness) and a flame ionization detector (FID). The oven temperature was programmed to hold at $40{ }^{\circ} \mathrm{C}$ for $7 \mathrm{~min}$, ramp to $270{ }^{\circ} \mathrm{C}$ at 10 ${ }^{\circ} \mathrm{C} / \mathrm{min}$, and hold at $270{ }^{\circ} \mathrm{C}$ for $20 \mathrm{~min}$. Injector and detector temperatures were maintained at 250 and $270{ }^{\circ} \mathrm{C}$, respectively. Each of the EO samples was diluted in hexane to a final concentration of $0.125 \mu \mathrm{l} / \mathrm{ml}$, and $1 \mu \mathrm{l}$ was injected into the GC in the splitless mode using helium as carrier gas. Each component was calculated by dividing the peak area of each component by the total area of all the components detected. The values were the mean of 3 
injections of each EO sample. All compounds were identified by comparison of their linear retention indices (RI) relative to the retention times of a homologous series of C5-C20 alkanes reported in the literature (Adams, 2007) and by comparison to the mass spectra from the NIST98 Mass Spectral Database.

Essential oils were evaluated first individually at the dose of $1.125 \mathrm{ml} / \mathrm{L}$ culture (trial 1) in 8 treatments: the 7 different EO and a control without EO (CTR). Because all the seven EO significantly decreased dry matter (DM) digestibility, neutral detergent fiber (NDF), and total VFA production at the dose tested, they were evaluated in three-way combinations (equal ratio) at a lower dose $(0.8 \mathrm{ml}$ total $\mathrm{EO} / \mathrm{L}$ culture $)$ in trial 2 using six treatments: control without EO (CTR); combination of DIL, ORE, and ROS (A); combination of CIL, ORE, and ROS (B); combination of CCB, EUC, and ORE (C); combination of CCB, DIL, and EUC (D); and combination of CIB, DIL, and ORE (E). These three-way EO combinations were chosen based on the different effects observed in trial 1. Each treatment of the two trials was done in triplicate.

\subsection{In vitro fermentations}

Fresh rumen content was collected from two rumen-cannulated lactating Jersey cows at $3 \mathrm{~h}$ post morning feeding. The animals were fed twice a day with a total mixed ration (TMR) composed of (DM basis) corn silage (390 g/kg), a mixture of alfalfa hay and grass hay (350 $\mathrm{g} / \mathrm{kg}$ ), and a concentrate mixture (260 g/kg) (crude protein, $162 \mathrm{~g} / \mathrm{kg}$; NDF, $351 \mathrm{~g} / \mathrm{kg}$; acid detergent fiber, $208 \mathrm{~g} / \mathrm{kg}$; lignin, $50 \mathrm{~g} / \mathrm{kg}$; DM basis). The cows were cared and handled following the protocols approved by The Ohio State University Animal Care and Use Committee. Rumen fluid was obtained by straining rumen content through four layers of cheesecloth into a bottle $(500 \mathrm{ml})$ leaving no headspace. The fresh rumen fluid samples from the two cows were combined in an equal volume, kept at $39^{\circ} \mathrm{C}$, and immediately transported 
to the laboratory within $15 \mathrm{~min}$ to be used as inoculum for the in vitro fermentations. The in vitro buffered medium (artificial saliva) was prepared anaerobically as described by Menke and Steingass (1988). Inside of an anaerobic chamber, $30 \mathrm{ml}$ of the medium and $10 \mathrm{ml}$ of the inoculum were dispensed into a $120 \mathrm{ml}$ serum bottle already containing $400 \mathrm{mg}$ of ground substrate as described by Patra and Yu (2014). The substrate was composed of alfalfa hay (388 g NDF per kg DM) and a concentrate mixture at equal ratio by weight. The concentrate mixture contained ground corn (730 g/kg), soy hulls $(150 \mathrm{~g} / \mathrm{kg})$, soybean meal $(80 \mathrm{~g} / \mathrm{kg})$, and a mineral vitamin mixture $(40 \mathrm{~g} / \mathrm{kg})$. The serum bottles were sealed with butyl rubber stoppers and incubated at $39{ }^{\circ} \mathrm{C}$ in a water bath for $24 \mathrm{~h}$ in trial 1 and for $48 \mathrm{~h}$ in trial 2 with intermittent shaking. Trial 1 was a preliminary experiment and for this reason, a shorter time of incubation $(24 \mathrm{~h})$ was used. Further, in trial 2 the effects of EO combinations were evaluated in $48 \mathrm{~h}$ of incubation to verify the possibility of a microbial adaptation of these compounds in cultures. microbial DNA extraction and analysis for VFA and ammonia. A pH meter (Fisher Scientific, Suwanee, USA) was used to measure the cultures $\mathrm{pH}$. The remaining culture was then filtered using a filter bag (Ankom Technology, Macedon, USA; pore size $50 \mu \mathrm{m}$ ) to 
al., 1991). Sodium sulphite was used in the NDF procedure without a heat stable amylase, and the results were expressed exclusive of residual ash. The VFA concentration of the culture was determined using GC as described by Patra and Yu (2014).

2.4. Microbial DNA extraction, quantitative real-time PCR, and denaturing gradient gel electrophoresis

Metagenomic DNA was extracted from microbial biomass pelleted from each culture following the method of Yu and Morrison (2004a). DNA quality was assessed by agarose gel (1.0\%) electrophoresis. The concentration and purity of the DNA extracts were assessed using a NanoDrop spectrophotometer (NanoDrop Technologies, Wilmington, USA). The DNA samples were stored at $-20{ }^{\circ} \mathrm{C}$ until further analysis. The abundance of total bacteria, archaea, protozoa, and select rumen bacterial species (including fibrolytic and hyperammonia producing bacteria) were quantified using respective specific quantitative real-time (qPCR) assays using respective specific PCR primer pair (Table 1) as described by Patra and Yu (2014). The absolute abundance was expressed as $\log _{10}$ of $r r s$ gene copies/ml of culture sample.

Denaturing gradient gel electrophoresis (DGGE) was used to profile the bacterial community and the archaeal community in the samples collected from trial 2 . The V3 hypervariable region of the rrs gene was amplified using bacterium- and archaeon-specific primers (with a 40-bp GC clamp added to the $5^{\prime}$ end of the forward primer; Table 1 ). The PCR and DGGE conditions and the gel image analysis were essentially the same as described previously (Yu et al., 2004b, 2008).

\subsection{Statistical analysis}


All data were analysed using the ANOVA procedure of SAS (SAS Institute Inc., 2010).

197

198

The qPCR data (rrs gene copies/ml of culture) were log-transformed before statistical analyses to improve normality. Differences between treatment means were determined by Tukey's test. Data were reported as least squares means \pm standard error. Differences were considered to be significant when $\mathrm{P} \leq 0.05$, while $0.05<\mathrm{P}<0.10$ were considered as a trend. The DGGE profile was analyzed using principal component analysis (PCA) using the PCORD program to assess the overall effect of EO on the bacterial community and the archaeal community.

\section{Results}

\subsection{Essential oil chemical composition}

The EO differ in their chemical compositions (Table 2). Overall, oxygenated monoterpenes were the major type of components of DIL, EUC, ORE, and ROS, whereas phenolic compounds were the major type of components of cinnamon EO (CIL, CIB, and CCB). Eight compounds were identified in DIL, representing $988 \mathrm{~g} / \mathrm{kg}$ of this EO. The major compounds were carvone (389 g/kg), limonene (216 g/kg), $\alpha$-phellandrene (210 g/kg), and dill ether (103 g/kg). The CIL, CIB, and CCB contained 20, 22, and 19 different identified compounds, which together accounted for $1000 \mathrm{~g} / \mathrm{kg}, 991 \mathrm{~g} / \mathrm{kg}$ and $988 \mathrm{~g} / \mathrm{kg}$ of each EO, respectively. Although these three EO were derived from different types of cinnamon and/or different parts of the same type of plant, their compositions were similar, with transcinnamaldehyde $(617 \mathrm{~g} / \mathrm{kg}, 517 \mathrm{~g} / \mathrm{kg}$ and $570 \mathrm{~g} / \mathrm{kg}$, respectively) as the main component. The other significant components were $\beta$-phellandrene (ranging from 43.0 to $63.2 \mathrm{~g} / \mathrm{kg}$ ), linalool (34.5 to $43.4 \mathrm{~g} / \mathrm{kg}$ ), and $\beta$-caryophyllene (62.6 to $92.8 \mathrm{~g} / \mathrm{kg}$ ). The CIB and CCB contained a higher amount of $\alpha$-terpinene, linalool and cis-cinnamaldehyde than CIL, while CIB contained a higher amount of $\alpha$-pinene, $\alpha$-phellandrene, $p$-cymene, $\beta$-caryophyllene and 
caryophyllene oxide but a lower proportion of eugenol than CIL and CCB. Nine compounds

222

223

were identified in EUC, with 1,8-cineole $(734 \mathrm{~g} / \mathrm{kg}), p$-cymene $(146 \mathrm{~g} / \mathrm{kg})$, and $\alpha$-pinene $(66.5 \mathrm{~g} / \mathrm{kg})$ as the major constituents. Ten compounds were identified in ORE, representing $997 \mathrm{~g} / \mathrm{kg}$ of this EO. The most abundant components were carvacrol $(522 \mathrm{~g} / \mathrm{kg}), \mathrm{m}$-cymene $(228 \mathrm{~g} / \mathrm{kg}), \gamma$-terpinene $(78.7 \mathrm{~g} / \mathrm{kg})$ and $\beta$-caryophyllene $(65.9 \mathrm{~g} / \mathrm{kg})$. The ROS contained 16 compounds accounting for $997 \mathrm{~g} / \mathrm{kg}$ of the whole oil. The main components were 1,8-cineole (356 g/kg), $\alpha$-pinene (122 g/kg), camphor (103 g/kg), limonene $(87.4 \mathrm{~g} / \mathrm{kg})$, and $\beta$-pinene $(81.2 \mathrm{~g} / \mathrm{kg})$.

3.2. Effects of essential oils, individually or in three-way combinations, on production of total gas and methane, ammonia concentrations, and feed degradability

All the EO, either alone or in three-way combinations, decreased $(\mathrm{P}<0.001)$ total gas production compared with control (Tables 3 and 4). The most pronounced inhibition on total gas production was observed with $\mathrm{CIB}, \mathrm{CCB}$, ORE, and with the EO combinations DILORE-ROS, CIL-ORE-ROS, and CIB-DIL-ORE. All the treatments also reduced $(\mathrm{P}<0.001)$ methane production (Tables 3 and 4). The EO combinations resulted in significant reduction (37.7\% to $78.5 \%)$ in methane production, but the magnitudes of the reduction were smaller than that achieved by the EO individually (Table 3). All the EO, both individually (except EUC) and in the three-way combinations significantly decreased $(\mathrm{P}<0.001)$ ammonia concentrations, with the largest decreases achieved by CIB (by 43.9\%; Table 3) and by the CIL-ORE-ROS combination (by 59.3\%; Table 4). All the treatments, except the CCB-DILEUC combination, decreased $(\mathrm{P}<0.001)$ DM digestibility without affecting NDF degradability (Table 3 and 4). The CCB resulted in the most pronounced (by 42\%) inhibition to DM digestibility. 

volatile fatty acid production.

The EO supplementations, either alone or in three-way combinations, had mixed effects on ruminal $\mathrm{pH}$ and VFA concentrations (Tables 3 and 4). The three EO from cinnamon (i.e., CCB, CIL, and CIB), ORE, and the EO combinations DIL-ORE-ROS, CIL-ORE-ROS, and CIB-DIL-ORE increased $(\mathrm{P}<0.001)$ culture $\mathrm{pH}$. Total VFA production was significantly $(\mathrm{P}<0.001)$ decreased (by up to $64 \%$ ) by all EO except EUC (Table 3). Among the EO combinations, DIL-ORE-ROS and CIB-DIL-ROS decreased VFA the most, while CCB-DILEUC decreased VFA the least (Table 4). The molar proportion of acetate was increased by DIL, CIL, and CCB but decreased by EUC and ROS (P<0.001). In contrast, none of the three-way combinations affected the molar proportion of acetate. Supplementation with CIB, $\mathrm{CCB}$, or ORE did not change the molar proportion of propionate in the cultures, but the other EO resulted in a decrease $(\mathrm{P}<0.001)$. Among the EO combinations, only CIL-ORE-ROS and CIB-DIL-ORE affected (increased, $\mathrm{P}<0.01$ ) the propionate proportion. All the EO showed mixed effects $(\mathrm{P}<0.001)$ on the molar proportion of butyrate, with DIL, EUC, and ROS increasing butyrate proportion, while $\mathrm{CIB}, \mathrm{CCB}$, and ORE decreased it (Table 3). On the contrary, all the EO combinations, except CCB-DIL-EUC, increased $(\mathrm{P}<0.001)$ butyrate proportion (Table 4). The molar proportion of isobutyrate was similar $(\mathrm{P}<0.05)$ among the treatments (Table 3), except the EO combinations DIL-ORE-ROS, CIL-ORE-ROS, and CIBDIL-ORE, all of which reduced $(\mathrm{P}<0.01)$ that measurement $($ Table 4$)$. The isovalerate concentration was lowered by $\operatorname{ROS}(\mathrm{P}<0.001)$ and the above three EO combinations $(\mathrm{P}<0.01)$. The molar proportion of valerate was affected $(\mathrm{P}<0.001)$ only by ROS that significantly increased it. Compared with that of the control, acetate to propionate ratio (A/P) was higher $(\mathrm{P}<0.001)$ with DIL, CIL, and EUC. The EO combination CIL-ORE-ROS also increased $(\mathrm{P}<0.05) \mathrm{A} / \mathrm{P}$ ratio. 
3.4. Effects of essential oils, individually or in three-way combinations, on the abundance of selected microbes

The effects of individual EO on the abundance of total bacteria, archaea, and the genus Prevotella was evaluated using qPCR (Table 5). The CIB, CCB, and ORE reduced $(\mathrm{P}<0.001)$ the abundance of total bacteria, confirming their strong antimicrobial potency. Except ORE, none of the EO decreased $(\mathrm{P}<0.001)$ the abundance of archaea, the microbial population directly responsible for rumen methane production. All the treatments significantly reduced $(\mathrm{P}<0.001)$ the abundance of the genus Prevotella, which includes proteolytic bacteria. The three-way EO combinations also affected the abundance of total bacteria, archaea, protozoa, and several cellulolytic, proteolytic, and hyper-ammonia producing bacteria (Table 6). A tendency $(\mathrm{P}=0.051)$ in reducing the abundance of total bacteria was observed for the EO combinations DIL-ORE-ROS and CCB-EUC-ORE. The abundance of archaea and protozoa was markedly decreased $(\mathrm{P}<0.001)$ by all the EO combinations. The populations of both Fibrobacter succinogenes and Ruminobacter amylophilus were significantly decreased $(\mathrm{P}<0.001)$ by all the treatments. On the contrary, the abundance of Ruminococcus albus was reduced $(\mathrm{P}<0.001)$ only by the CIL-ORE-ROS combination and increased by the CCB-DILORE combination, while the abundance of Ruminococcus flavefaciens was not affected by any of the treatments.

The three-way EO combinations showed mixed effects on the abundance of proteolytic and ammoniagenic bacteria. The abundance of Prevotella ruminicola was lowered $(\mathrm{P}<0.001)$ only by the CCB-EUC-ORE combination, while that of Prevotella bryantii showed a tendency $(\mathrm{P}=0.08)$ to be lowered by all the treatments. The abundance of Selenomonas ruminantium was reduced $(\mathrm{P}<0.01)$ with the DIL-ORE-ROS and the CCB-EUC-ORE combinations. However, none of the EO combinations affected the abundance of Clostridium 
aminophilum, a hyper-ammonia producing bacterium. The EO combinations DIL-ORE-ROS,

CIL-ORE-ROS, and CIB-DIL-ORE increased $(\mathrm{P}<0.01)$ the abundance of Streptococcus bovis, whereas all but the CCB-DIL-EUC combination reduced $(\mathrm{P}<0.001)$ the abundance of Megasphaera elsdenii.

3.5. Effects of three-way essential oil combinations on the bacterial and archaeal communities

When the bacterial and the archaeal communities of the in vitro cultures were profiled using DGGE, differences in banding patterns were noted between the EO combination treatments and the control and among the different EO combinations (Figure 1A and 2A).

The PCA plots of the bacterial DGGE profiles indicated that the EO combinations resulted in apparent changes in some bacterial populations (Figure 1B and 1C). The first three principal components (PC's) together explained $63.19 \%$ of the total variation, with the first principal component (PC1) explaining $35.91 \%$ of the total variation (Figure 1B and 1C). The DIL-

ORE-ROS and the CIB-DIL-ORE combinations resulted in the most noticeable changes in the bacterial communities. The PCA plots of archaeal DGGE profiles demonstrated that the archaeal communities apparently differed among the treatments (Figure $2 \mathrm{~B}$ and $2 \mathrm{C}$ ). The first three PC's explained $73.97 \%$ of the total variability, with the PC1 explaining $37.47 \%$ of the variability. The archaeal communities were separated into three clusters along PC1: combinations CCB-EUC-ORE and CCB-DIL-EUC, combinations DIL-ORE-ROS and CILORE-ROS, and the control and combination CIB-DIL-ORE. The PC2, which explained $25.03 \%$ of the variability, separated combinations DIL-ORE-ROS and CIL-ORE-ROS from the other EO combinations. Both combinations DIL-ORE-ROS and CIL-ORE-ROS contained ORE and ROS, while combinations CCB-EUC-ORE and CCB-DIL-EUC both contained CCB and EUC. 


\section{Discussion}

Essential oils are complex mixture of plant secondary metabolites with highly variable composition. For this reason, their mode of action against microorganisms or specific cellular targets is often difficult to determine and thus still remains poorly understood (Cobellis et al., 2016). In an attempt to link differences in mitigating methane production to specific component(s) of the EO, the chemical compositions of seven EO were determined. The seven EO differ in proportion in almost all the component identified, including monoterpene hydrocarbons (e.g. $\alpha$-pinene, $\alpha$-phellandrene, 1,8-cineole, carvone, $p$-cymene, $m$-cymene, limonene, camphor, and dill ether), phenolic compounds (e.g. carvacrol, transcinnamaldehyde, and eugenol). As discussed below, the anti-methanogenic potency of an EO is necessarily attributable to its major compound.

Methane production was completely inhibited by $\mathrm{CIB}, \mathrm{CCB}$, and ORE individually. Because DM and NDF digestibility, total gas production, and VFA were only partially inhibited, these three EO were more inhibitory to methanogens than to bacteria. However, the cinnamon oil from cinnamon leaves (CIL) decreased methane production to a lesser degree than the EO from cinnamon bark. Variable methane inhibition has been reported in the literature. Several studies have reported strong inhibition to methane production by cinnamon EO and oregano EO. For example, Macheboeuf et al. (2008) achieved 98\% inhibition of methane production using $5 \mathrm{mM}$ of oregano EO or cinnamon EO. While evaluating five different EO (EO from clove, eucalyptus, garlic, oregano, and peppermint), Patra and Yu (2012) recorded the greatest methane reduction (by 87\%) by oregano EO at the dose of 1.0 $\mathrm{g} / \mathrm{L}$. Dose-dependent inhibition to methane production in vitro by Ceylon cinnamon bark EO $\mu 1 /$ L. In contrast, Roy et al. (2014) observed only slight inhibition (5.3\%) of methane 
production by cinnamon oil (its source was not reported) at $600 \mathrm{mg} / \mathrm{L}$. It is tempting to

347 speculate that trans-cinnamaldehyde, which is the major compound in CCB and CIB, and carvacrol, which is the major compound of ORE, may be primarily responsible for the observed methane inhibition. However, CIL and CCB and CIB have similar composition except a lower proportion of cis-cinnamaldehyde (6.90 vs. $25.0 \mathrm{~g} / \mathrm{kg})$, and CIL decreased methane to a less extent than $\mathrm{CCB}$ or $\mathrm{CIB}$. These results suggest importance of some minor EO compounds in determining anti-methanogenic activities. Systematic studies are needed to evaluate each of the compounds in these EO to determine their potency to lower methane production. cinnamon oil and ORE, with EUC being least inhibitory. These observations are in general agreement with those reported by other researchers, but greater inhibition was achieved in the present study than in other studies: $47.5 \%$ inhibition by DIL vs. $12 \%$ inhibition reported by Macheboeuf et al. (2008), 18.7\% inhibition by EUC vs. $12 \%$ inhibition reported by Patra and Yu (2012), 43.5\% inhibition by ROS vs. 24.0\% inhibition reported by Roy et al. (2014). The discrepancy may be attributed to differences in the source and dose of the EO used. However, the lack of information of the source and chemical compositions of the EO used in the other studies makes it to pinpoint a specific cause for the discrepancy. than that achieved by the EO individually. Because less EO, in total, was used when evaluated in combination than when evaluated individually ( 0.8 vs. $1.125 \mathrm{ml} / \mathrm{L})$, the decreased inhibition to methane production might be attributed to the lower EO dose used in the EO combinations. However, potential antagonism among EO components from different 
much lower dose used in the EO combinations. In fact, some EO compounds, even if present at low concentrations, may interact with the main compounds, affecting their biological activity. For example, Burt et al. (2004) reported a synergism between cinnamaldehyde and eugenol, both of which are present in cinnamon EO, and their interaction was thought to be responsible of the higher anti-methanogenic activity of cinnamon oil than that of cinnamaldehyde alone. Lin et al. (2012) tested mixtures of EO from thyme, oregano, cinnamon, and lemon in five different ratios in vitro. They observed that mixtures containing more phenol-based EO (EO from thyme and oregano) than aldehyde-based EO (EO from cinnamon and lemon) decreased methane production to a greater extent than the mixtures containing more aldehyde-based EO than phenol-based EO. A mixture of EO compounds (eugenol, carvacrol, citral, and cinnamaldehyde) was found more effective in reducing methane production (by 70.8\%) in equal ratio than in unequal ratios (Lin et al., 2013a), suggesting that proportions among different EO components may affect their antimicrobial activity. Moreover, when a commercial mixture of EO (thymol, eugenol, vanillin, and limonene) was offered to beef cattle ( 1 and $2 \mathrm{~g} / \mathrm{d} / \mathrm{animal})$, no effect on methane production were observed (Tomkins et al., 2015). The results from the present study and previous studies suggest complex interactions among EO components, between EO and feed, and between EO and rumen microbiota, and additional research is needed to determine the optimal EO combination, dose, and ratio to achieve most effective methane mitigation in livestock production and to avoid detrimental effect on feed digestion or fermentation.

The observed decrease in ammonia concentrations, with the largest decrease achieved by CIB, corroborates the study by Macheboeuf et al. (2008) who showed that transcinnamaldehyde and cinnamon EO lowered ammonia concentrations greater than other EO and EO compounds evaluated. It was proposed that EO decrease rumen ammonia concentration by inhibiting proteolysis, peptidolysis, and/or amino acid deamination, 
especially deamination by hyper-ammonia producing bacteria (Patra, 2011). Several studies showed that the effective dose of EO to decrease ammonia production was lower than that needed to decrease methane production (Macheboeuf et al., 2008; Lin et al., 2012; Patra and Yu, 2012; Cobellis et al., 2015). In the present study, however, methane production was decreased to greater magnitudes compared to that of ammonia production, suggesting a weaker dose effect on ammonia production than on methane production.

The observed adverse effects of EO on feed digestion could be a consequence of a broad non-specific antimicrobial activity. Some authors suggested that EO could decrease protein and starch degradation by inhibiting amylolytic and proteolytic bacteria without affecting fiber degradation (Patra, 2011). Unfortunately, feed additives that decrease feed digestibility will not result in net reductions in methane emissions per unit of animal product (Knapp et al., 2014). For this reason, CCB-DIL-EUC is the most promising EO combination as it led to effective inhibition to production of both methane and ammonia without adversely effecting feed digestibility.

A number of studies showed that total VFA concentrations were not or only slightly affected by EO at low doses but decreased at high doses (Patra, 2011; Cobellis et al., 2015). Combinations of eugenol, carvacrol, citral, and cinnamaldeyde, in different ratios and at different levels, showed similar effects on methane reduction, but combinations of aldehyderich mixture led to greater inhibition to total VFA than combinations of phenol-rich mixture (Lin et al., 2013a). The effects of EO on total VFA concentrations may also depend on other factors, such as type of substrate and medium conditions. Data from a meta-analysis revealed that concentrations of total VFA and propionate changed linearly and positively with decreased methane production. Acetate production and A/P ratio increased linearly with increasing inhibition of methane by EO (Patra, 2010). Unlike other phytochemicals, EO may decrease methane production by directly inhibiting methanogens and by inhibiting hydrogen- 
producing bacteria, such as Lachnospira multiparus, $R$. albus and $R$. flavefaciens and protozoa. Considering the effect on DM degradability, total VFA, and A/P ratio, the CCBDIL-EUC combination may a promising EO that warrants further evaluation.

The observed decrease in abundance of archaea and protozoa by the EO combinations is consistent with the finding of a few previous studies, both in vitro and in vivo (Lin et al., 2012, 2013a, 2013b). It should be noted that individual EO markedly decreased methane production without decreasing the abundance of archaea after $24 \mathrm{~h}$ of incubation (except ORE), while all the three-way EO combinations lowered both methane production and the archaeal population after $48 \mathrm{~h}$ of incubation. This discrepancy might be attributable to the longer incubation time of the EO combinations and/or potential synergic anti-methanogenic activity between compounds of different EO. Archaea rely on methanogenesis for energy conservation, and thus decrease in methanogen population is expected with a reduced methane production during prolonged incubation. Besides, as suggested by Ohene-Adjei et al. (2008), EO may cause changes in archaeal community and/or in activity of methanogenesis pathway, eventually decreasing methanogen abundance and methane production. Besides, some methanogens are associated with protozoa, and protozoa-associated methanogens can contribute 9-37\% of the rumen methane production (Szumacher-Strabel and Cieślak, 2010). Thus, EO might have decreased methanogen abundance and methanogenesis by decreasing abundance of protozoa. Similarly, the reduction of protozoal abundance by EO might have also contributed to the reduction of ammonia in the in vitro cultures.

Among the three major cellulolytic bacterial species, $F$. succinogenes appeared to be more sensitive to the EO combinations than the two Ruminococcus species ( $R$. albus and $R$. flavefaciens). This observation is in general agreement with that reported by Patra and $\mathrm{Yu}$ (2012). The discord between significant decrease in the abundance of $F$. succinogenes and null effect on NDF degradability in all the treatments suggests that $F$. succinogenes had little 
impact on the NDF degradability in the EO-treated cultures. Alternatively, other cellulolytic bacteria might have occupied the niche left by $F$. succinogenes. clove, oregano, and peppermint) on some protein-degrading bacteria in mixed rumen cultures (Patra and $\mathrm{Yu}, 2014$ ). That study showed that EO were effective in reducing the abundance of $P$. ruminicola, $P$. bryantii and $S$. ruminantium. The present study corroborates that precious study with respect to inhibiting the aforementioned proteolytic bacteria by EO. Hyperammonia producing bacterium C. aminophilum was also lowered by oregano EO (Patra and Yu, 2014). In the present study, oregano EO was not evaluated individually for its effects on hyper-ammonia producing bacteria, and the EO combinations containing oregano EO (from oregano leaves) did not decrease $C$. aminophilum. The stimulatory effect of EO on S. bovis is in general agreement with the low susceptibility of this species to EO in pure cultures (Evans and Martin, 2000) and with the increase of S. bovis by EO reported by Patra and Yu (2014). It was hypothesized that the increase of $S$. bovis population by EO was due to decrease in competing microbial populations. archaeal populations had different sensitivity to the three-way EO combinations used in the present study. In a recent study, Patra and Yu (2012) observed that different EO, when tested individually at different doses, changed the composition of both archaeal and bacterial communities to different extents in a dose-dependent manner. Evaluating the effects of some EO on archaeal communities in sheep rumen, Ohene-Adjei et al. (2008) also reported varying effects on archaeal community. The authors of that study attributed the EO effect to the effect of EO against rumen protozoa. Future research to determine the methanogens associated with rumen protozoa will help test that hypothesis. 


\section{Conclusions}

The present study demonstrated that EO differ in chemical composition and have different effect on the same microbes. Different groups of rumen microbes also differ in sensitivity to the same EO. The EO effects may not necessarily be attributable to the major component in some EO. The EO containing a phenolic (e.g., carvacrol) or a carbonyl (e.g., cinnamaldehyde) compound demonstrated a stronger antimicrobial activity than EO that contain monoterpenes. Interactions among different EO and different EO components may affect their antimicrobial activity. Combinations of EO at moderate dose may be an effective approach to mitigate methane emission and nitrogen excretion from cattle with little or no adverse effect on rumen feed digestion or fermentation. Combination of EO from Ceylon cinnamon bark, dill seeds, and eucalyptus leaves may be a promising EO combination.

\section{Conflict of interest}

None of the authors has any financial or personal interest that would inappropriately influence or bias the contents of this paper.

\section{Acknowledgements}

G. Cobellis's tenure at The Ohio State University was supported by a grant from the University of Perugia $(\mathrm{PhD}$ research project in Animal Health, Livestock Production and Food Safety, XXVIII cycle). This material is based upon work that is partially supported by the National Institute of Food and Agriculture, U.S. Department of Agriculture, under award number 2012-67015-19437. 


\section{References}

Adams, R.P., 2007. Identification of essential oil components by gas chromatography/mass spectrometry, fourth ed. Allured publishing corporation.

AOAC International, Latimer, G.W., 2012. Official methods of analysis of AOAC International. AOAC International.

Bekele, A.Z., Koike, S., Kobayashi, Y., 2010. Genetic diversity and diet specificity of ruminal Prevotella revealed by $16 \mathrm{~S}$ rRNA gene-based analysis. FEMS Microbiol. Lett. $305,49-57$.

Benchaar, C., Greathead, H., 2011. Essential oils and opportunities to mitigate enteric methane emissions from ruminants. Anim. Feed Sci. Technol. 166, 338-355.

Burt, S., 2004. Essential oils: their antibacterial properties and potential applications in foods - a review. Int. J. Food Microbiol. 94, 223-253.

Cobellis, G., Petrozzi, A., Forte, C., Acuti, G., Orrù, M., Marcotullio, M.C., Aquino, A., Nicolini, A., Mazza, V., Trabalza-Marinucci, M., 2015. Evaluation of the Effects of mitigation on methane and ammonia production by using Origanum vulgare L. and Rosmarinus officinalis L. essential oils on in vitro rumen fermentation systems. Sustainability $7,12856-12869$.

Cobellis, G., Trabalza-Marinucci, M., Yu, Z., 2016. Critical evaluation of essential oils as rumen modifiers in ruminant nutrition: A review. Sci. Total Environ. 545, 556-568.

Evans, J.D., Martin, S.A., 2000. Effects of thymol on ruminal microorganisms. Curr. Microbiol. 41, 336-340.

FAO, 2013. Greenhouse gas emissions from ruminant supply chains, a global life cycle assessment. FAO, Rome.

Hristov, A.N., Oh, J., Firkins, J.L., Dijkstra, J., Kebreab, E., Waghorn, G., Makkar, H.P., Adesogan, A.T., Yang, W., Lee, C., Gerber, P.J., Henderson, B., Tricarico, J.M., 2013. 
Special topics - Mitigation of methane and nitrous oxide emissions from animal operations: I. A review of enteric methane mitigation options. J. Anim. Sci. 91, 50455069.

Knapp, J.R., Laur, G.L., Vadas, P.A., Weiss, W.P., Tricarico, J.M., 2014. Invited review: Enteric methane in dairy cattle production: Quantifying the opportunities and impact of reducing emissions. J. Dairy Sci. 97, 3231-3261.

Koike, S., Kobayashi, Y., 2001. Development and use of competitive PCR assays for the rumen cellulolytic bacteria: Fibrobacter succinogenes, Ruminococcus albus and Ruminococcus flavefaciens. FEMS Microbiol. Lett. 204, 361-366.

Lane, D.J., 1991. 16S/23S rRNA sequencing. In: Stackebrandt E. and Goodfellow M. (eds), Nucleic Acid Techniques in Bacterial Systematics. John Wiley and Sons, Chichester, United Kingdom, pp. 115-175.

Lin, B., Lu, Y., Wang, J.H., Liang, Q., Liu, J.X., 2012. The effects of combined essential oils along with fumarate on rumen fermentation and methane production in vitro. J. Anim. Feed Sci. 575, 54.

Lin, B., Wang, J.H., Lu, Y., Liang, Q., Liu, J.X., 2013a. In vitro rumen fermentation and methane production are influenced by active components of essential oils combined with fumarate. J. Anim. Physiol. Anim. Nutr. 97, 1-9.

Lin, B., Lu, Y., Salem, A.Z.M., Wang, J.H., Liang, Q., Liu, J.X., 2013b. Effects of essential oil combinations on sheep ruminal fermentation and digestibility of a diet with fumarate included. Anim. Feed Sci. Technol. 184, 24-32.

Macheboeuf, D., Morgavi, D.P., Papon, Y., Mousset, J.L., Arturo-Schaan, M., 2008. Doseresponse effects of essential oils on in vitro fermentation activity of the rumen microbial population. Anim. Feed Sci. Technol. 145, 335-350. 
Menke, K.H., Steingass, H., 1988. Estimation of the energetic feed value obtained from chemical analysis and in vitro gas production using rumen fluid. Anim. Res. Dev. 28, 7 55.

Nadkarni, M.A., Martin, F.E., Jacques, N.A., Hunter, N., 2002. Determination of bacterial load by real-time PCR using a broad-range (universal) probe and primers set. Microbiol. $148,257-266$.

Ohene-Adjei, S., Chaves, A.V., McAllister, T.A., Benchaar, C., Teather, R.M., Forster, R.J., 2008. Evidence of increased diversity of methanogenic archaea with plant extract supplementation. Microb. Ecol. 56, 234-242.

Patra, A.K., 2010. Meta-analyses of effects of phytochemicals on digestibility and rumen fermentation characteristics associated with methanogenesis. J. Sci. Food Agric. 90, 2700-2708.

Patra, A.K., 2011. Effects of essential oils on rumen fermentation, microbial ecology and ruminant production. Asian J. Anim. Vet. Adv. 6, 416-428.

Patra, A.K., Yu, Z., 2012. Effects of essential oils on methane production and fermentation by, and abundance and diversity of, rumen microbial populations. Appl. Environ. Microbiol. 78, 4271-4280.

Patra, A.K., Yu, Z., 2014. Effects of vanillin, quillaja saponin, and essential oils on in vitro fermentation and protein-degrading microorganisms of the rumen. Appl. Microbiol. Biot. 98, 897-905.

Pawar, M.M., Kamra, D.N., Agarwal, N., Chaudhary, L.C., 2014. Effects of essential oils on in vitro methanogenesis and feed fermentation with buffalo rumen liquor. Agric. Res. 3, $67-74$. 
Roy, D., Tomar, S.K., Sirohi, S.K., Kumar, V., Kumar, M., 2014. Efficacy of different essential oils in modulating rumen fermentation in vitro using buffalo rumen liquor. Vet. World 7, 213-218.

SAS Institute Inc. JMP® 9 Basic Analysis and Graphing. Cary, NC: SAS Institute Inc. 2010.

Stiverson, J., Morrison, M., Yu, Z., 2011. Populations of select cultured and uncultured bacteria in the rumen of sheep and the effect of diets and ruminal fractions. Int. J. Microbiol. 2011.

Sylvester, J.T., Karnati, S.K., Yu, Z., Morrison, M., Firkins, J.L., 2004. Development of an assay to quantify rumen ciliate protozoal biomass in cows using real-time PCR. J. Nutr. $134,3378-3384$.

Szumacher-Strabel, M., Cieślak, A., 2010. Potential of phytofactors to mitigate rumen ammonia and methane production. J. Anim. Feed Sci. 19, 319-337.

Tajima, K., Aminov, R.I., Nagamine, T., Matsui, H., Nakamura, M., Benno, Y., 2001. Dietdependent shifts in the bacterial population of the rumen revealed with real-time PCR. Appl. Environ. Microbiol. 67, 2766-2774.

Tomkins, N.W., Denman, S.E., Pilajun, R., Wanapat, M., McSweeney, C.S., Elliott, R., 2015. Manipulating rumen fermentation and methanogenesis using an essential oil and monensin in beef cattle fed a tropical grass hay. Anim. Feed Sci. Technol. 200, 25-34.

Van Soest, P.J., Robertson, J.B., Lewis, B.A., 1991. Methods for dietary fiber, neutral detergent fiber, and non-starch polysaccharides in relation to animal nutrition. J. Dairy Sci. 74, 3583-3597.

Yu, Z., Michel, F.C., Hansen, G., Wittum, T., Morrison, M., 2005. Development and application of real-time PCR assays for quantification of genes encoding tetracycline resistance. Appl. Environ. Microbiol. 71, 6926-6933. 
591 Yu, Z., Garcia-Gonzalez, R., Schanbacher, F.L., Morrison, M., 2008. Evaluations of different

592

593

594

595

596

597

598

599

600

601

602

603

\section{(1)} hypervariable regions of archaeal $16 \mathrm{~S}$ rRNA genes in profiling of methanogens by archaea-specific PCR and denaturing gradient gel electrophoresis. Appl. Environ. Microbiol. 74, 889-893.

Yu, Z., Morrison, M., 2004a. Improved extraction of PCR-quality community DNA from digesta and fecal samples. Biotechniques, 36, 808-813.

Yu, Z., Morrison, M., 2004b. Comparisons of different hypervariable regions of rrs genes for use in fingerprinting of microbial communities by PCR-denaturing gradient gel electrophoresis. Appl. Environ. Microbiol. 70, 4800-4806. 
605 Figure 1. DGGE profile (A) and PCA plots (B and C) of bacterial community. CTR (•):

606 control; A ( $\mathbf{\square})$ : combination of dill seeds, oregano leaves, rosemary leaves; B ( $\Delta)$ : 607 combination of cinnamon leaves, oregano leaves, rosemary leaves; C ( ): combination of 608 Ceylon cinnamon bark, eucalyptus leaves, oregano leaves; D ( $\square$ ): combination of Ceylon 609 cinnamon bark, dill seeds, eucalyptus leaves; E (+): combination of cinnamon bark, dill 610 seeds, oregano leaves.

611

612 Figure 2. DGGE profile (A) and PCA plots (B and C) of archaea. CTR (•): control; A (匹): 613 combination of dill seeds, oregano leaves, rosemary leaves; B $(\boldsymbol{\Delta})$ : combination of cinnamon 614 leaves, oregano leaves, rosemary leaves; C ( $\bullet$ : combination of Ceylon cinnamon bark, 615 eucalyptus leaves, oregano leaves; D (口): combination of Ceylon cinnamon bark, dill seeds, 616 eucalyptus leaves; E (+): combination of cinnamon bark, dill seeds, oregano leaves. 
Table 1. Specific primers used for qPCR analysis and DGGE technique.

\begin{tabular}{|c|c|c|c|c|c|}
\hline Organisms & Primers & Sequences $\left(5^{\prime} \rightarrow 3^{\prime}\right)$ & $\begin{array}{c}\text { Annealing } \\
\left({ }^{\circ} \mathrm{C}\right)\end{array}$ & $\begin{array}{l}\text { Size } \\
(\mathrm{bp})\end{array}$ & References \\
\hline \multicolumn{6}{|c|}{ Real-time PCR } \\
\hline \multirow{2}{*}{ Total bacteria } & $27 f$ & AGA GTT TGA TCM TGG CTC AG & \multirow{2}{*}{55} & \multirow{2}{*}{1535} & \multirow{2}{*}{ Lane 1991} \\
\hline & $1525 \mathrm{r}$ & AAG GAG GTG WTC CAR CC & & & \\
\hline \multirow{3}{*}{ Total bacteria } & Eub358f & TCC TAC GGG AGG CAG CAG T & \multirow[b]{2}{*}{60} & \multirow{3}{*}{448} & \multirow[b]{2}{*}{$\begin{array}{l}\text { Nadkarni } \\
\text { et al. } 2002\end{array}$} \\
\hline & Eub806r & $\begin{array}{l}\text { GGA CTA CCA GGG TAT CTA ATC } \\
\text { CTG TT }\end{array}$ & & & \\
\hline & $\begin{array}{l}\text { TaqMan } \\
\text { probe }\end{array}$ & $\begin{array}{l}\text { 6-FAM-5'-CGT ATT ACC GCG GCT } \\
\text { GCT GGC AC-3'-TAMRA }\end{array}$ & 70 & & \\
\hline \multirow{2}{*}{ Archaea } & $\mathrm{ARC} 787 \mathrm{f}$ & ATT AGA TAC CCS BGT AGT CC & \multirow{2}{*}{60} & \multirow{2}{*}{272} & \multirow{2}{*}{$\begin{array}{l}\text { Yu et al. } \\
2005\end{array}$} \\
\hline & ARC1059r & GCC ATG CAC CWC CTC T & & & \\
\hline \multirow{2}{*}{ Protozoa } & $316 \mathrm{f}$ & GCT TTC GWT GGT AGT GTA TT & \multirow{2}{*}{54} & \multirow{2}{*}{223} & \multirow{2}{*}{$\begin{array}{l}\text { Sylvester } \\
\text { et al. } 2004\end{array}$} \\
\hline & $539 \mathrm{r}$ & CTT GCC CTC YAA TCG TWC T & & & \\
\hline \multirow{2}{*}{$\begin{array}{l}\text { Fibrobacter } \\
\text { succinogenes }\end{array}$} & Fs219f & GGT ATG GGA TGA GCT TGC & \multirow[b]{2}{*}{63} & \multirow[b]{2}{*}{446} & \multirow{2}{*}{$\begin{array}{l}\text { Koike and } \\
\text { Kobayashi } \\
2001\end{array}$} \\
\hline & Fs654r & GCC TGC CCC TGA ACT ATC & & & \\
\hline \multirow{2}{*}{$\begin{array}{l}\text { Ruminococcus } \\
\text { flavefaciens }\end{array}$} & Rf154f & TCT GGA AAC GGA TGG TA & \multirow{2}{*}{55} & \multirow{2}{*}{295} & \multirow{2}{*}{$\begin{array}{l}\text { Koike and } \\
\text { Kobayashi } \\
2001\end{array}$} \\
\hline & Rf425r & CCT TTA AGA CAG GAG TTT ACA A & & & \\
\hline \multirow{2}{*}{$\begin{array}{l}\text { Ruminococcus } \\
\text { albus }\end{array}$} & Ra1281f & CCC TAA AAG CAG TCT TAG TTC G & \multirow[b]{2}{*}{55} & \multirow[b]{2}{*}{175} & Koike and \\
\hline & Ra1439r & CCT CCT TGC GGT TAG AAC A & & & $\begin{array}{l}\text { Kobayashi } \\
2001\end{array}$ \\
\hline $\begin{array}{l}\text { Ruminobacter } \\
\text { amylophilus }\end{array}$ & $\begin{array}{l}\text { Ram-F } \\
\text { Ram-R }\end{array}$ & $\begin{array}{l}\text { CAA CCA GTC GCA TTC AGA } \\
\text { CAC TAC TCA TGG CAA CAT }\end{array}$ & 57 & 642 & $\begin{array}{l}\text { Tajima et } \\
\text { al. } 2001\end{array}$ \\
\hline Prevotella & P.rumi-F & GGT TAT CTT GAG TGA GTT & & & Bekele et \\
\hline ruminicola & P.rumi-R & CTG ATG GCA ACT AAA GAA & 53 & 485 & al. 2010 \\
\hline Prevotella & P.brya-F & ACT GCA GCG CGA ACT GTC AGA & 67 & 540 & Bekele et \\
\hline bryantii & P.brya-R & ACC TTA CGG TGG CAG TGT CTC & 01 & 540 & al. 2010 \\
\hline Prevotella & BAC $303 f$ & GAA GGT CCC CCA CAT TG & 56 & 418 & Stiverson \\
\hline spp. & BAC708r & CAA TCG GAG TTC TTC GTG & 50 & 410 & \\
\hline $\begin{array}{l}\text { Clostridium } \\
\text { aminophilum }\end{array}$ & $\begin{array}{l}\text { C.amin-57F } \\
\text { C.amin- } \\
616 \mathrm{R}\end{array}$ & $\begin{array}{l}\text { ACG GAA ATT ACA GAA GGA AG } \\
\text { GTT TCC AAA GCA ATT CCA C }\end{array}$ & 57 & 560 & $\begin{array}{l}\text { Patra and } \\
\text { Yu } 2014\end{array}$ \\
\hline $\begin{array}{l}\text { Streptococcus } \\
\text { bovis }\end{array}$ & $\begin{array}{l}\text { S. bovis-F } \\
\text { S. bovis-R }\end{array}$ & $\begin{array}{l}\text { CTA ATA CCG CAT AAC AGC AT } \\
\text { AGA AAC TTC CTA TCT CTA GG }\end{array}$ & 57 & 869 & $\begin{array}{l}\text { Bekele et } \\
\text { al. } 2010\end{array}$ \\
\hline Megashaera & M. elsd-F & GAC CGA AAC TGC GAT GCT AGA & 58 & 130 & Bekele et \\
\hline elsdenii & M. elsd-R & CGC CTC AGC GTC AGT TGT C & 30 & 150 & al. 2010 \\
\hline Selenomonas & S. rumi-F & TGC TAA TAC CGA ATG TTG & 53 & 513 & Bekele et \\
\hline ruminantium & S. rumi-R & TCC TGC ACT CAA GAA AGA & 53 & 513 & al. 2010 \\
\hline & & $\begin{array}{r}\text { PCR-DGGE } \\
\end{array}$ & & & \\
\hline Total & GC-A357f & CCC TAC GGG GCG CAG CAG & & & Yu and \\
\hline bacteria & $519 \mathrm{r}$ & GWA TTA CCG CGG CKG CTG & $61 \rightarrow 56^{\circ} \mathrm{C}$ & 194 & $\begin{array}{l}\text { Morrison } \\
2004 b\end{array}$ \\
\hline Archaea & $\begin{array}{l}\text { GC-RC344f } \\
519 r\end{array}$ & $\begin{array}{l}\text { ACG GGG YGC AGC AGG CGC GA } \\
\text { GWA TTA CCG CGG CKG CTG }\end{array}$ & $61 \rightarrow 56^{\circ} \mathrm{C}$ & 191 & $\begin{array}{l}\text { Yu et al. } \\
2008\end{array}$ \\
\hline
\end{tabular}

FAM: 6-carboxyfluorescein; TAMRA: 6-carboxytetramethylrhodamine 
Table 2. Compounds identified in each EO.

\begin{tabular}{|c|c|c|c|c|c|c|c|}
\hline \multirow[t]{2}{*}{ Component $^{\mathrm{a}}$} & \multicolumn{7}{|c|}{ Sources of essential oils $(\mathrm{g} / \mathrm{kg})^{\mathrm{b}}$} \\
\hline & DIL & CIL & CIB & $\mathrm{CCB}$ & EUC & ORE & ROS \\
\hline$\alpha$-Thujene & - & $3.00 \pm 1.00$ & $4.50 \pm 1.00$ & $2.10 \pm 2.30$ & - & - & - \\
\hline$\alpha$-Pinene & $14.4 \pm 2.10$ & $13.0 \pm 1.70$ & $21.3 \pm 3.70$ & $12.0 \pm 1.20$ & $66.5 \pm 2.50$ & $20.6 \pm 4.40$ & $122 \pm 5.00$ \\
\hline Camphene & - & $4.40 \pm 1.70$ & $6.80 \pm 1.60$ & $4.70 \pm 3.80$ & - & - & $48.9 \pm 7.50$ \\
\hline$\beta$-Pinene & - & $4.90 \pm 1.10$ & $7.60 \pm 1.10$ & $5.20 \pm 3.50$ & $14.9 \pm 0.90$ & $11.9 \pm 3.10$ & $81.2 \pm 6.30$ \\
\hline Myrcene & - & - & - & - & - & $26.8 \pm 2.90$ & $27.7 \pm 2.20$ \\
\hline$\beta$-Myrcene & - & - & - & - & $13.9 \pm 0.80$ & - & - \\
\hline 3-Octanol & - & - & - & - & - & $12.2 \pm 1.90$ & - \\
\hline$\alpha$-Phellandrene & $210 \pm 9.60$ & $22.8 \pm 2.00$ & $38.9 \pm 0.20$ & $20.3 \pm 1.80$ & $5.10 \pm 1.50$ & - & - \\
\hline$\Delta^{3}$-Carene & - & - & - & - & - & - & $15.2 \pm 0.80$ \\
\hline$\alpha$-Terpinene & - & $7.80 \pm 1.30$ & $9.20 \pm 1.50$ & $9.20 \pm 1.20$ & $3.40 \pm 0.40$ & - & - \\
\hline$p$-Cymene & $21.5 \pm 1.60$ & $22.8 \pm 1.80$ & $31.9 \pm 1.80$ & $26.4 \pm 2.80$ & $146 \pm 2.70$ & - & $17.2 \pm 3.10$ \\
\hline$m$-Cymene & - & - & - & - & - & $228 \pm 9.30$ & - \\
\hline Limonene & $216 \pm 3.00$ & - & - & - & - & - & $87.4 \pm 3.10$ \\
\hline$\beta$-Phellandrene & - & $46.7 \pm 1.60$ & $69.2 \pm 1.40$ & $43.0 \pm 2.50$ & - & - & - \\
\hline 1,8-Cineole & - & - & - & - & $734 \pm 3.20$ & - & $356 \pm 13.0$ \\
\hline$\gamma$-Terpinene & - & - & - & - & $6.60 \pm 0.20$ & $78.7 \pm 5.20$ & $16.3 \pm 0.70$ \\
\hline Linaool & - & $34.5 \pm 2.90$ & $42.5 \pm 2.70$ & $43.4 \pm 1.80$ & - & $6.40 \pm 4.30$ & $16.9 \pm 2.80$ \\
\hline Camphor & - & - & - & - & - & - & $103 \pm 7.20$ \\
\hline Borneol & - & - & - & - & - & - & $15.2 \pm 1.40$ \\
\hline Terpinene-4-ol & - & $5.90 \pm 2.90$ & $5.70 \pm 3.00$ & $5.20 \pm 1.60$ & - & - & - \\
\hline$\alpha$-Terpineol & - & $8.50 \pm 1.20$ & $8.10 \pm 1.10$ & $8.30 \pm 2.40$ & $6.70 \pm 3.30$ & - & - \\
\hline Bornyl acetate & - & - & - & - & - & - & $18.6 \pm 1.00$ \\
\hline Dill ether & $103 \pm 6.80$ & - & - & - & - & - & - \\
\hline $\begin{array}{l}\text { cis- } \\
\text { Dihydrocarvone }\end{array}$ & $9.50 \pm 3.40$ & - & - & - & - & - & - \\
\hline $\begin{array}{l}\text { trans- } \\
\text { Dihydrocarvone }\end{array}$ & $25.7 \pm 4.10$ & - & - & - & - & - & - \\
\hline $\begin{array}{l}\text { cis- } \\
\text { Cinnamaldehyde }\end{array}$ & - & $6.90 \pm 2.00$ & $25.0 \pm 2.00$ & $25.9 \pm 1.70$ & - & - & - \\
\hline Carvone & $389 \pm 6.90$ & - & - & - & - & - & - \\
\hline $\begin{array}{l}\text { trans- } \\
\text { Cinnamaldehyde }\end{array}$ & - & $617 \pm 6.80$ & $517 \pm 6.70$ & $570 \pm 2.10$ & - & - & - \\
\hline$\alpha$-Humulene & - & - & - & - & - & - & $16.7 \pm 3.00$ \\
\hline$\beta$-Caryophyllene & - & $62.6 \pm 9.70$ & $92.8 \pm 9.70$ & $69.6 \pm 2.00$ & - & $65.9 \pm 5.10$ & $46.0 \pm 2.90$ \\
\hline Carvacrol & - & - & - & - & - & $522 \pm 18.5$ & - \\
\hline Eugenol & - & $57.8 \pm 6.50$ & $16.3 \pm 2.60$ & $55.0 \pm 2.20$ & - & - & - \\
\hline$\alpha$-Copaene & - & $13.1 \pm 2.60$ & $18.9 \pm 5.60$ & $13.4 \pm 3.20$ & - & - & - \\
\hline$\beta$-Bourbonene & - & - & $6.30 \pm 0.80$ & - & - & - & - \\
\hline$\beta$-Elemene & - & - & $6.10 \pm 0.90$ & - & - & - & - \\
\hline $\begin{array}{l}\text { trans-Cinnamyl } \\
\text { acetate }\end{array}$ & - & $31.4 \pm 7.50$ & $12.7 \pm 2.50$ & $39.4 \pm 1.20$ & - & - & - \\
\hline $\begin{array}{l}\text { Caryophyllene } \\
\text { oxide }\end{array}$ & - & $6.30 \pm 1.60$ & $25.9 \pm 4.10$ & $5.40 \pm 3.10$ & - & $7.70 \pm 0.70$ & $9.00 \pm 5.80$ \\
\hline Humulene oxide & - & $24.9 \pm 4.10$ & $16.5 \pm 1.00$ & $28.1 \pm 3.80$ & - & - & - \\
\hline Benzyl benzoate & - & $5.30 \pm 1.10$ & $7.60 \pm 1.60$ & $5.10 \pm 4.00$ & - & - & - \\
\hline TOTAL & 988 & 1000 & 991 & 993 & 997 & 997 & 997 \\
\hline $\begin{array}{l}\text { Monoterpene } \\
\text { hydrocarbons }\end{array}$ & 462 & 125 & 189 & 124 & 257 & 382 & 416 \\
\hline $\begin{array}{l}\text { Oxygenated } \\
\text { monoterpenes }\end{array}$ & 526 & 48.9 & 56.3 & 56.9 & 740 & 529 & 509 \\
\hline Sesquiterpenes & - & 75.7 & 124 & 83.0 & - & 65.9 & 62.7 \\
\hline $\begin{array}{l}\text { Oxygenated } \\
\text { sesquiterpenes }\end{array}$ & - & 31.2 & 42.4 & 33.5 & - & 7.70 & 9.00 \\
\hline Phenolics & - & 718 & 579 & 691 & - & - & - \\
\hline Alcohols & - & - & - & - & - & 12.2 & - \\
\hline
\end{tabular}


$622{ }^{a}$ Compounds listed in order of their elution from GC. ${ }^{\mathrm{b}}$ Each value (mean \pm standard deviation) represents the 623 mean of three GC-MS runs. Sources of EO, DIL: dill seeds; CIL: cinnamon leaves; CIB: cinnamon bark; CCB: 624 Ceylon cinnamon bark; EUC: eucalyptus leaves; ORE: oregano leaves; ROS: rosemary leaves.

625

626

627

628

629

630

631

632

633

634

635

636

637

638

639

640

641

642

643

644

645

646

647

648

649

650 
651 Table 3. Effects of different essential oils $(1.125 \mathrm{ml} / \mathrm{L})$ on in vitro gas production and fermentation

652 characteristics.

\begin{tabular}{|c|c|c|c|c|c|c|c|c|c|c|}
\hline \multirow{2}{*}{ Parameters } & \multirow[b]{2}{*}{ CTR } & \multicolumn{7}{|c|}{ Sources of essential oils ${ }^{*}$} & \multirow{2}{*}{ SEM ${ }^{*}$} & \multirow{2}{*}{ P-value } \\
\hline & & DIL & CIL & CIB & CCB & EUC & ORE & ROS & & \\
\hline Total gas (ml) & $127^{\mathrm{a}}$ & $109^{c}$ & $97.9^{d}$ & $83.4^{\mathrm{e}}$ & $83.0^{\mathrm{e}}$ & $120^{\mathrm{b}}$ & $81.5^{\mathrm{e}}$ & $111^{\mathrm{c}}$ & 1.38 & $<0.001$ \\
\hline Methane (ml) & $11.9^{\mathrm{a}}$ & $6.25^{\mathrm{c}}$ & $3.67^{\mathrm{d}}$ & $0.00^{\mathrm{e}}$ & $0.00^{\mathrm{e}}$ & $9.67^{\mathrm{b}}$ & $0.00^{\mathrm{e}}$ & $6.72^{c}$ & 0.40 & $<0.001$ \\
\hline Ammonia (mg/dL) & $22.0^{\mathrm{a}}$ & $15.2^{\mathrm{bc}}$ & $13.5^{\mathrm{bc}}$ & $12.3^{\mathrm{c}}$ & $13.3^{\mathrm{bc}}$ & $17.8^{\mathrm{ab}}$ & $16.1^{\mathrm{bc}}$ & $14.7^{\mathrm{bc}}$ & 0.94 & $<0.001$ \\
\hline $\mathrm{DMD}^{*}$ & $0.65^{\mathrm{a}}$ & $0.55^{\mathrm{b}}$ & $0.46^{\mathrm{c}}$ & $0.43^{\mathrm{cd}}$ & $0.38^{\mathrm{d}}$ & $0.57^{\mathrm{b}}$ & $0.41^{\mathrm{cd}}$ & $0.55^{\mathrm{b}}$ & 0.02 & $<0.001$ \\
\hline NDFD* & 0.71 & 0.70 & 0.71 & 0.68 & 0.66 & 0.69 & 0.69 & 0.71 & 0.02 & 0.164 \\
\hline $\mathrm{pH}$ & $6.11^{\mathrm{c}}$ & $6.20^{c}$ & $6.43^{\mathrm{b}}$ & $6.95^{\mathrm{a}}$ & $6.98^{\mathrm{a}}$ & $6.18^{c}$ & $7.02^{\mathrm{a}}$ & $6.26^{\mathrm{bc}}$ & 0.04 & $<0.001$ \\
\hline Total VFA* ${ }^{*}(\mathrm{mM})$ & $42.1^{\mathrm{a}}$ & $25.0^{\mathrm{c}}$ & $21.1^{\mathrm{d}}$ & $15.1^{\mathrm{e}}$ & $15.4^{\mathrm{e}}$ & $41.5^{\mathrm{a}}$ & $15.4^{\mathrm{e}}$ & $36.9^{\mathrm{b}}$ & 0.74 & $<0.001$ \\
\hline Acetate $(\%)^{\#}$ & $55.2^{\mathrm{c}}$ & $58.7^{\mathrm{ab}}$ & $60.2^{\mathrm{a}}$ & $57.9^{\mathrm{abc}}$ & $58.3^{\mathrm{ab}}$ & $42.3^{\mathrm{e}}$ & $57.4^{\mathrm{bc}}$ & $45.1^{\mathrm{d}}$ & 0.56 & $<0.001$ \\
\hline Propionate $(\%)^{\#}$ & $20.8^{\mathrm{a}}$ & $14.6^{\mathrm{cd}}$ & $16.3^{\mathrm{b}}$ & $20.0^{\mathrm{a}}$ & $20.1^{\mathrm{a}}$ & $13.1^{\mathrm{d}}$ & $20.0^{\mathrm{a}}$ & $15.6^{\mathrm{bc}}$ & 0.31 & $<0.001$ \\
\hline Isobutyrate $(\%)^{\#}$ & $1.27^{\mathrm{ab}}$ & $1.39^{\mathrm{ab}}$ & $1.26^{\mathrm{ab}}$ & $1.58^{\mathrm{ab}}$ & $1.46^{\mathrm{ab}}$ & $1.25^{\mathrm{ab}}$ & $1.83^{\mathrm{a}}$ & $1.07^{\mathrm{b}}$ & 0.14 & $<0.05$ \\
\hline Butyrate $(\%)^{\#}$ & $18.0^{\mathrm{d}}$ & $21.4^{\mathrm{c}}$ & $18.4^{\mathrm{d}}$ & $15.8^{\mathrm{e}}$ & $15.7^{\mathrm{e}}$ & $38.0^{\mathrm{a}}$ & $15.8^{\mathrm{e}}$ & $32.1^{\mathrm{b}}$ & 0.41 & $<0.001$ \\
\hline Isovalerate $(\%)^{\#}$ & $2.03^{\mathrm{ab}}$ & $1.89^{\mathrm{abc}}$ & $1.84^{\mathrm{bc}}$ & $2.21^{\mathrm{ab}}$ & $2.16^{\mathrm{ab}}$ & $1.91^{\mathrm{abc}}$ & $2.42^{\mathrm{a}}$ & $1.50^{\mathrm{c}}$ & 0.11 & $<0.001$ \\
\hline Valerate $(\%)^{\#}$ & $2.61^{\mathrm{bc}}$ & $1.98^{\mathrm{c}}$ & $2.07^{\mathrm{c}}$ & $2.45^{\mathrm{bc}}$ & $2.31^{\mathrm{c}}$ & $3.38^{\mathrm{b}}$ & $2.54^{\mathrm{bc}}$ & $4.59^{\mathrm{a}}$ & 0.20 & $<0.001$ \\
\hline $\mathrm{A} / \mathrm{P}^{*}$ ratio & $2.66^{\mathrm{c}}$ & $4.03^{\mathrm{a}}$ & $3.70^{\mathrm{a}}$ & $2.89^{b c}$ & $2.90^{\mathrm{bc}}$ & $3.22^{\mathrm{b}}$ & $2.87^{\mathrm{bc}}$ & $2.90^{\mathrm{bc}}$ & 0.07 & $<0.001$ \\
\hline
\end{tabular}

653 *DIL: dill seeds; CIL: cinnamon leaves; CIB: cinnamon bark; CCB: Ceylon cinnamon bark; EUC: eucalyptus

654 leaves; ORE: oregano leaves; ROS: rosemary leaves; SEM: standard error means; DMD: dry matter

655 degradability; NDFD: neutral detergent fiber degradability; VFA: volatile fatty acid; A/P: acetate/propionate.

656 " Molar proportion as \% of total VFA.

657 Means $(\mathrm{n}=3)$ with different superscripts within a row differ significantly $(\mathrm{P}<0.05)$.

658

659

660

661

662

663

664

665

666

667

668

669 
670 Table 4. Effects of three-way essential oil combinations $(0.8 \mathrm{ml} / \mathrm{L}$ total $)$ on in vitro gas production and 671 fermentation characteristics.

\begin{tabular}{|c|c|c|c|c|c|c|c|c|}
\hline \multirow{2}{*}{ Parameters } & \multirow[b]{2}{*}{ CTR } & \multicolumn{5}{|c|}{ Three-way essential oil combinations ${ }^{*}$} & \multirow{2}{*}{ SEM $^{*}$} & \multirow{2}{*}{ P-value } \\
\hline & & A & $\mathrm{B}$ & $\mathrm{C}$ & $\mathrm{D}$ & $\mathrm{E}$ & & \\
\hline Total gas (ml) & $147^{\mathrm{a}}$ & $120^{\mathrm{b}}$ & $119^{\mathrm{b}}$ & $126^{\mathrm{b}}$ & $129^{\mathrm{b}}$ & $120^{\mathrm{b}}$ & 2.43 & $<0.001$ \\
\hline Methane (ml) & $15.7^{\mathrm{a}}$ & $9.77^{\mathrm{b}}$ & $3.37^{\mathrm{c}}$ & $7.65^{\mathrm{b}}$ & $7.48^{\mathrm{b}}$ & $8.41^{\mathrm{b}}$ & 0.53 & $<0.001$ \\
\hline Ammonia (mg/dL) & $44.8^{\mathrm{a}}$ & $20.5^{\mathrm{bc}}$ & $18.3^{\mathrm{c}}$ & $25.9^{\mathrm{b}}$ & $22.7^{\mathrm{bc}}$ & $19.7^{\mathrm{bc}}$ & 1.44 & $<0.001$ \\
\hline $\mathrm{DMD}^{*}$ & $0.74^{\mathrm{a}}$ & $0.54^{\mathrm{c}}$ & $0.56^{\mathrm{c}}$ & $0.61^{\mathrm{b}}$ & $0.71^{\mathrm{a}}$ & $0.54^{\mathrm{c}}$ & 0.01 & $<0.001$ \\
\hline NDFD* & 0.73 & 0.73 & 0.70 & 0.71 & 0.71 & 0.72 & 0.02 & 0.680 \\
\hline $\mathrm{pH}$ & $6.99^{\mathrm{b}}$ & $7.17^{\mathrm{a}}$ & $7.20^{\mathrm{a}}$ & $7.10^{\mathrm{ab}}$ & $7.01^{\mathrm{b}}$ & $7.15^{\mathrm{a}}$ & 0.02 & $<0.001$ \\
\hline Total VFA* $(\mathrm{mM})$ & $56.0^{\mathrm{a}}$ & $42.6^{\mathrm{bc}}$ & $46.9^{\mathrm{abc}}$ & $51.3^{\mathrm{ab}}$ & $48.7^{\mathrm{abc}}$ & $39.1^{\mathrm{c}}$ & 2.45 & $<0.01$ \\
\hline Acetate $(\%)^{\#}$ & 59.0 & 62.2 & 61.1 & 59.6 & 59.7 & 61.9 & 0.57 & 0.167 \\
\hline Propionate $(\%)^{\#}$ & $19.4^{\mathrm{a}}$ & $14.7^{\mathrm{abc}}$ & $13.1^{\mathrm{c}}$ & $15.5^{\mathrm{abc}}$ & $18.5^{\mathrm{ab}}$ & $13.9^{\mathrm{bc}}$ & 0.86 & $<0.01$ \\
\hline Isobutyrate $(\%)^{\#}$ & $2.56^{\mathrm{a}}$ & $1.52^{\mathrm{b}}$ & $1.26^{\mathrm{b}}$ & $1.77^{\mathrm{ab}}$ & $1.57^{\mathrm{ab}}$ & $1.36^{\mathrm{b}}$ & 0.17 & $<0.01$ \\
\hline Butyrate $(\%)^{\#}$ & $12.5^{\mathrm{c}}$ & $17.0^{\mathrm{ab}}$ & $20.8^{\mathrm{a}}$ & $18.3^{\mathrm{ab}}$ & $15.6^{\mathrm{bc}}$ & $19.3^{\mathrm{ab}}$ & 0.73 & $<0.001$ \\
\hline Isovalerate $(\%)^{\#}$ & $4.07^{\mathrm{a}}$ & $2.35^{\mathrm{b}}$ & $1.97^{\mathrm{b}}$ & $2.71^{\mathrm{ab}}$ & $2.55^{\mathrm{ab}}$ & $1.81^{\mathrm{b}}$ & 0.26 & $<0.01$ \\
\hline Valerate $(\%)^{\#}$ & 2.59 & 2.14 & 1.78 & 2.10 & 2.13 & 1.63 & 0.21 & 0.127 \\
\hline $\mathrm{A} / \mathrm{P}^{*}$ ratio & $3.05^{\mathrm{b}}$ & $4.28^{\mathrm{ab}}$ & $4.74^{\mathrm{a}}$ & $3.85^{\mathrm{ab}}$ & $3.23^{\mathrm{ab}}$ & $4.61^{\mathrm{ab}}$ & 0.35 & $<0.05$ \\
\hline
\end{tabular}

672 *CTR: control; A: combination of dill seeds, oregano leaves, rosemary leaves; B: combination of cinnamon

673 leaves, oregano leaves, rosemary leaves; C: combination of Ceylon cinnamon bark, eucalyptus leaves, oregano

674 leaves; D: combination of Ceylon cinnamon bark, dill seeds, eucalyptus leaves; E: combination of cinnamon

675 bark, dill seeds, oregano leaves; SEM: standard error means; DMD: dry matter degradability; NDFD: neutral

676 detergent fiber degradability; VFA: volatile fatty acid; A/P: acetate/propionate.

677 \# Molar proportion as \% of total VFA.

678 Means $(\mathrm{n}=3)$ with different superscripts within a row differ significantly $(\mathrm{P}<0.05)$. 
Table 5. Effects of different essential oils $(1.125 \mathrm{ml} / \mathrm{L})$ on abundance $\left(\log _{10} r r s\right.$ copies $\left./ \mathrm{ml}\right)$ of total bacteria, archaea, and Prevotella spp.

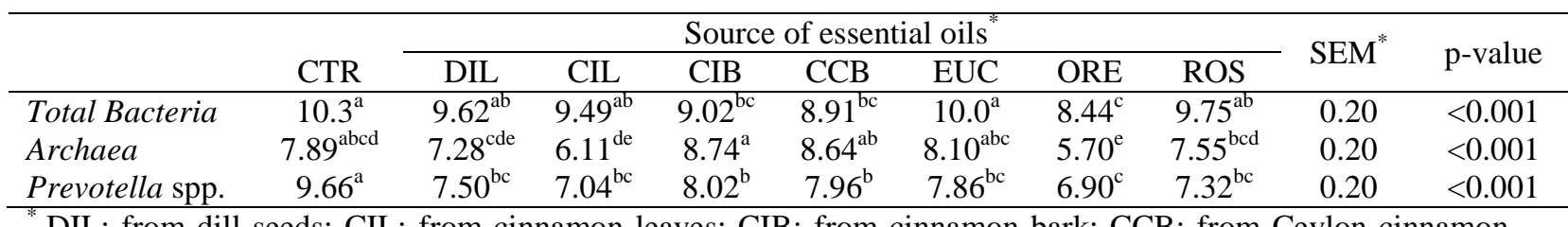

681 "DIL: from dill seeds; CIL: from cinnamon leaves; CIB: from cinnamon bark; CCB: from Ceylon cinnamon

682 bark; EUC: from eucalyptus leaves; ORE: from oregano leaves; ROS: from rosemary leaves; SEM: standard

683 error means.

684 Means $(\mathrm{n}=3)$ with different superscripts within a row differ significantly $(\mathrm{p}<0.05)$.

685

686

687

688

689

690

691

692

693

694

695

696

697

698

699

700

701

702

703

704 
Table 6. Effects of three-way essential oil combinations $(0.8 \mathrm{ml} / \mathrm{L})$ on abundance $\left(\log _{10} r r s\right.$ copies $\left./ \mathrm{ml}\right)$ of total

707 bacteria, archaea, protozoa and selected bacteria species.

\begin{tabular}{|c|c|c|c|c|c|c|c|c|}
\hline & \multirow[b]{2}{*}{ CTR } & \multicolumn{5}{|c|}{ Three-way essential oil combinations ${ }^{*}$} & \multirow{2}{*}{ SEM $^{*}$} & \multirow{2}{*}{ p-value } \\
\hline & & $\mathrm{A}$ & $\mathrm{B}$ & $\mathrm{C}$ & $\mathrm{D}$ & $\mathrm{E}$ & & \\
\hline Total Bacteria & 11.1 & 11.0 & 11.0 & 10.3 & 11.3 & 11.1 & 0.08 & 0.051 \\
\hline Archaea & $8.32^{\mathrm{a}}$ & $7.53^{\mathrm{b}}$ & $7.47^{\mathrm{b}}$ & $7.68^{\mathrm{b}}$ & $7.85^{\mathrm{b}}$ & $7.59^{\mathrm{b}}$ & 0.10 & $<0.001$ \\
\hline Protozoa & $7.92^{\mathrm{a}}$ & $6.23^{\mathrm{b}}$ & $5.96^{\mathrm{b}}$ & $5.92^{\mathrm{b}}$ & $6.19^{\mathrm{b}}$ & $5.99^{\mathrm{b}}$ & 0.19 & $<0.001$ \\
\hline Fibrobacter succinogenes & $9.60^{\mathrm{a}}$ & $6.93^{c}$ & $6.91^{\mathrm{c}}$ & $7.09^{c}$ & $8.13^{\mathrm{b}}$ & $7.05^{\mathrm{c}}$ & 0.10 & $<0.001$ \\
\hline Ruminococcus albus & $9.20^{\mathrm{b}}$ & $8.82^{\mathrm{bc}}$ & $8.48^{c}$ & $8.83^{\mathrm{bc}}$ & $9.90^{\mathrm{a}}$ & $8.86^{\mathrm{bc}}$ & 0.10 & $<0.001$ \\
\hline Ruminobacter amylophilus & $9.53^{\mathrm{a}}$ & $8.43^{b}$ & $8.40^{\mathrm{b}}$ & $8.40^{\mathrm{b}}$ & $8.73^{b}$ & $8.49^{\mathrm{b}}$ & 0.09 & $<0.001$ \\
\hline Ruminococcus flavefaciens & $9.42^{\mathrm{ab}}$ & $9.06^{\mathrm{ab}}$ & $8.67^{b}$ & $9.80^{\mathrm{a}}$ & $10.1^{\mathrm{a}}$ & $9.06^{\mathrm{ab}}$ & 0.23 & $<0.01$ \\
\hline Prevotella ruminicola & $9.54^{\mathrm{ab}}$ & $9.22^{\mathrm{abc}}$ & $9.06^{\mathrm{bc}}$ & $8.69^{c}$ & $9.69^{\mathrm{a}}$ & $9.00^{\mathrm{bc}}$ & 0.12 & $<0.001$ \\
\hline Prevotella bryantii & 8.91 & 7.22 & 7.01 & 8.10 & 7.27 & 7.33 & 0.45 & 0.080 \\
\hline Selenomonas ruminantium & $9.39^{\mathrm{a}}$ & $8.92^{b}$ & $9.10^{\mathrm{ab}}$ & $8.82^{b}$ & $9.05^{\mathrm{ab}}$ & $9.08^{\mathrm{ab}}$ & 0.07 & $<0.01$ \\
\hline Clostridium aminophilum & 8.54 & 8.35 & 8.25 & 8.38 & 8.99 & 8.81 & 0.18 & 0.072 \\
\hline Streptococcus bovis & $7.85^{\mathrm{b}}$ & $10.0^{\mathrm{a}}$ & $10.4^{\mathrm{a}}$ & $9.14^{\mathrm{ab}}$ & $9.24^{\mathrm{ab}}$ & $10.7^{\mathrm{a}}$ & 0.46 & $<0.01$ \\
\hline Megasphaera elsdenii & $0.48^{\mathrm{a}}$ & $-1.52^{b}$ & $-1.33^{b}$ & $-1.34^{b}$ & $0.10^{\mathrm{a}}$ & $-1.11^{\mathrm{b}}$ & 0.11 & $<0.001$ \\
\hline
\end{tabular}

708

"CTR: control; A: combination of dill seeds, oregano leaves, rosemary leaves; B: combination of cinnamon

leaves, oregano leaves, rosemary leaves; C: combination of Ceylon cinnamon bark, eucalyptus leaves, oregano

710

leaves; D: combination of Ceylon cinnamon bark, dill seeds, eucalyptus leaves; E: combination of cinnamon

711

bark, dill seeds, oregano leaves; SEM: standard error means.

712

Means ( $\mathrm{n}=3)$ with different superscripts within a row differ significantly $(\mathrm{p}<0.05)$.

713

714

715

716

717

718

719

720

721

722 
Figure 1.

730

731

732

733

734

735

736

737

738

739

740

(A)

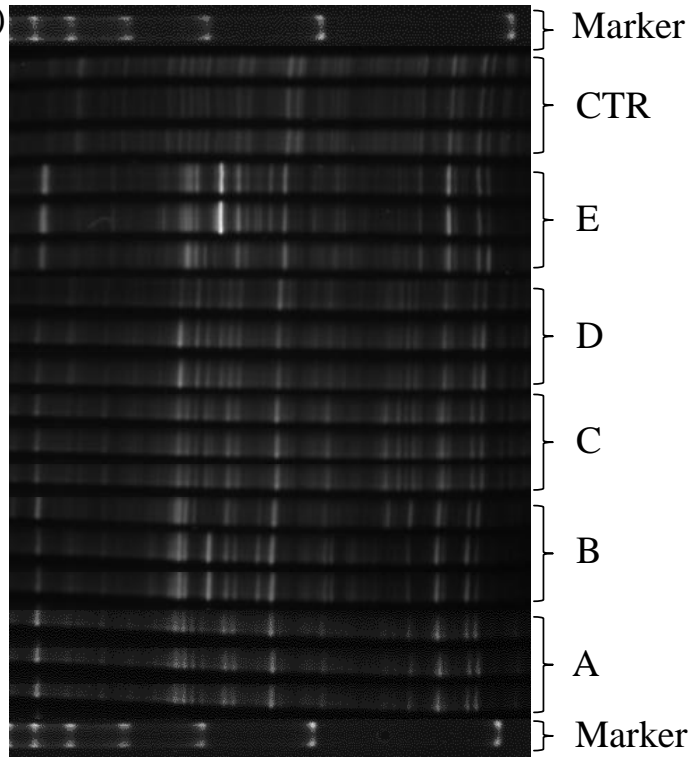

(B)

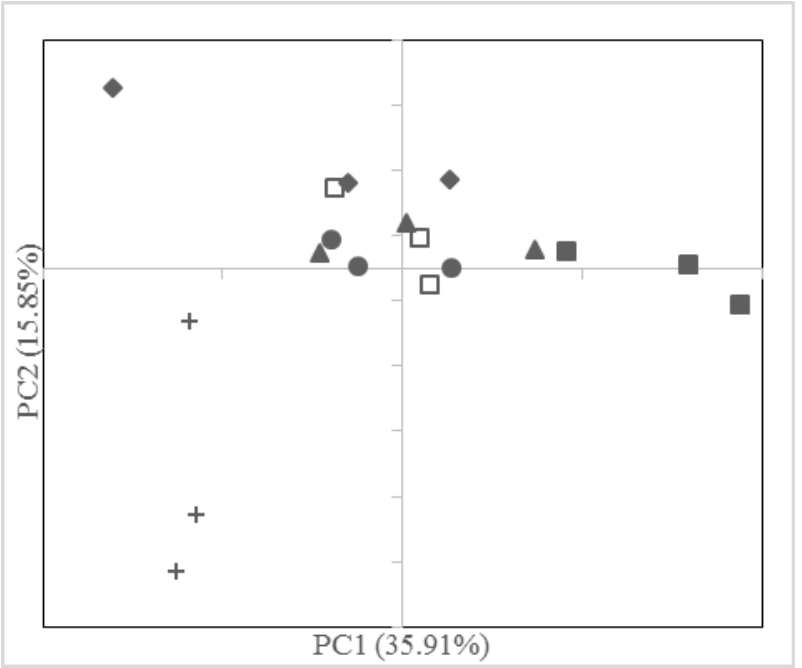

(C)

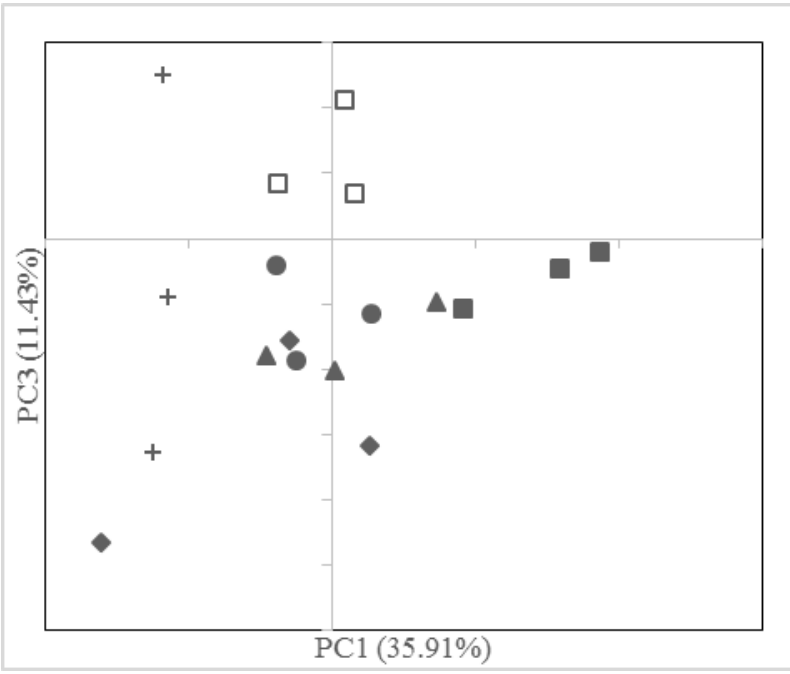

744

745

746

747

748

749 
Figure 2.

751

752

753

754

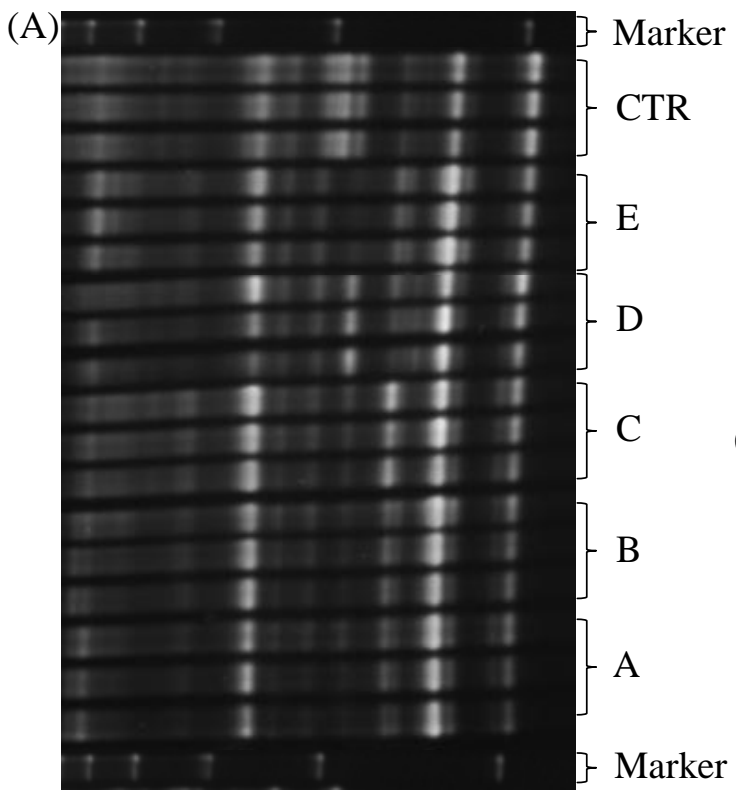

(B)

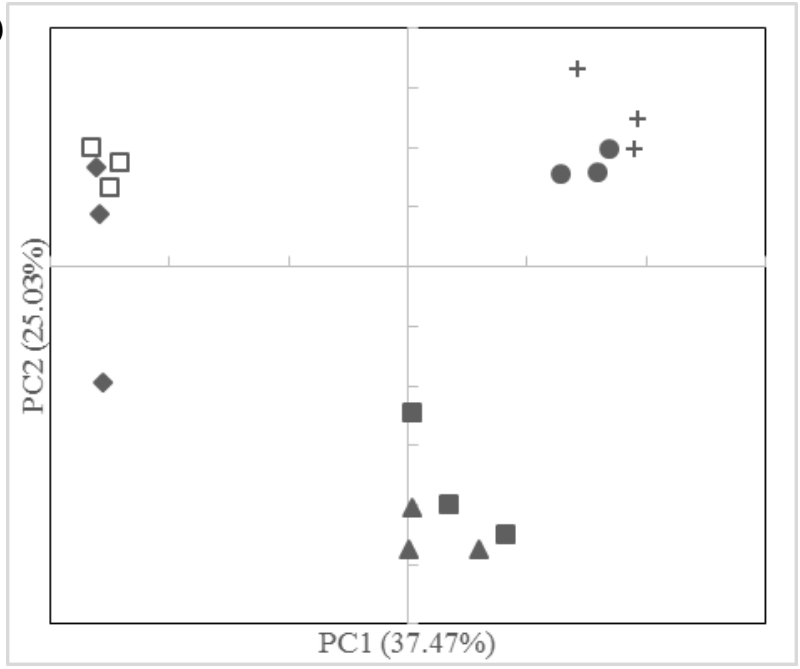

(C)

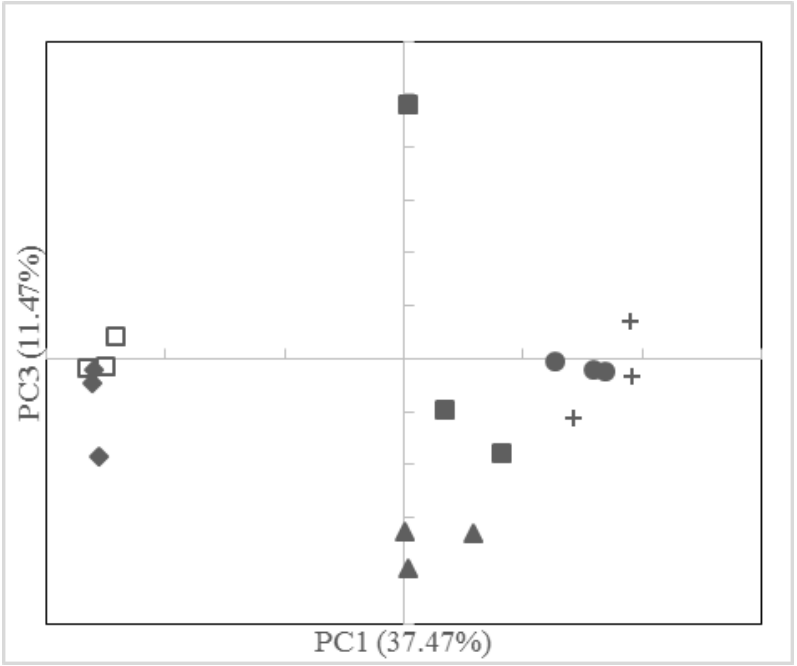

